\title{
Original article (Orijinal araştırma) \\ Reproductive performance and mating behavior of the predatory bug, Anthocoris minki Dohrn, 1860 (Hemiptera: Anthocoridae)
}

\author{
Predatör böcek Anthocoris minki Dohrn (Heteroptera: Anthocoridae)'nin üreme \\ performansı ve çiftleşme davranışları
}

\author{
Abdalla E. T. ADAM ${ }^{1^{*}} \quad$ Ertan YANIK $^{2} \quad$ Denis Tange ACHIRI ${ }^{3}$ \\ Abstract
}

Anthocoris minki Dohrn, 1860 (Hemiptera: Anthocoridae) is a potential predator for biological control of the pistachio psyllid, Agonoscena pistaciae Burckhardt \& Lauterer, 1989 (Hemiptera: Psyllidae) in pistachio orchards. This study aimed to examine the impact of mating behavior on the reproductive output of $A$. minki. The study was conducted under the laboratory conditions in 2015 at Harran University. Males and females of $A$. minki used in the experiments were obtained from laboratory-reared population and female mating behavior and fertilization capacity of males were investigated. In the multiple mating, matings made after the first copulation had an adverse effect on egg deposition. Mated females deposited significantly fewer eggs in the presence of males than in their absence. Male fertilization capability was evaluated by enabling a single virgin male to mate sequentially with three virgin females in different intervals between mating events. Regardless of the length of interval between mating events, the number of eggs laid by the first-mated female was significantly greater than the number of eggs laid by the second- or thirdmated females. The study suggests that achievement of economic and large-scale rearing of $A$. minki can be done if the post-mating interactions that negatively influence the female reproduction and longevity are understood and handled appropriately.

Keywords: Anthocoris minki, mating, reproductive performance

\section{Öz}

Anthocoris minki Dohrn, 1860 (Heteroptera: Anthocoridae), antepfıstığı bahçelerinde yaygın olan antepfıstığı psillidi Agonoscena pistaciae Burckhardt \& Lauterer, 1989 (Hemiptera: Psyllidae)'nin biyolojik mücadelesinde potensiyel bir predatördür. Bu çalışmada, A. minkinin çiftleşme davranışlarının, üremesi üzerine olan etkisinin araştırıması amaçlanmıştır. Çalışma, 2015 yılında Harran Üniversitesi'nde laboratuvar koşullarında yürütülmüştür. Denemelerde kullanılan $A$. minkinin erkek ve dişi bireyleri, laboratuvarda üretilen popülasyondan elde edilmiştir ve dişilerin çiftleşme davranışları ve erkeklerin dölleme kapasitesi incelenmiştir. Çoklu çiftleşme denemelerinde, ilk çiftleşmeden sonra olan çiftleşmelerin yumurta bırakma üzerine olumsuz bir etki gösterdiği görülmüştür. Çiftleşmiş dişilerin erkek varlığında bıraktığı yumurta sayısı, erkek yokluğuna göre daha az olduğu saptanmıştır. Erkeklerin dölleme kapasitesini değerlendirmek amacıyla çiftleşmeler arasında farklı aralıklarla ilk kez çiftleşecek erkekler, sırayla hiç çiftleşmemiş üç dişi ile çiftleştirilmiştir. Çiftleşmeler arasında verilen süreye bakılmaksızın, ilk çiftleşen dişi tarafından bırakılan toplam yumurta sayısı, ikinci veya üçüncü çiftleşen dişi tarafından bırakılan yumurta sayısından daha fazla olduğu belirlenmiştir. Çalışma, $A$. minki dişilerinin üremesini ve yaşam süresini olumsuz etkileyen çiftleşme sonrası etkileşimlerinin anlaşılıp, uygun bir şekilde yönetildiğinde bu böceklerin ekonomik ve geniş çapta üretilmesinin başarılabileceği önermektedir.

Anahtar sözcükler: Anthocoris minki, çiftleşme, üreme performansı

\footnotetext{
${ }^{1}$ University of Zalingei, Faculty of Agriculture, Department of Plant Protection, 63314, Zalingei, Sudan

${ }^{2}$ Karabük University, Faculty of Forestry, Department of Forest Entomology, 78050, Karabük, Turkey

${ }^{3}$ Çukurova University, Faculty of Agriculture, Department of Plant Protection, 01330, Sarıçam, Adana, Turkey

* Corresponding author (Sorumlu yazar) e-mail: kalus120@yahoo.com

Received (Alınış): 04.12.2017 Accepted (Kabul ediliş): 04.05.2018 


\section{Introduction}

In simple terms, the biological control of insects is an essential component of any integrated management program as an ecosystem-based strategy focuses on long-term prevention of insects or their damage. Successful biological control significantly depends on the natural enemies and their ability to adapt to the habitat and to their hosts. Good understanding of the factors affecting the ability of biological control agents to rapidly increase their own populations in the ecosystem is also considered an important step. Post-mating interactions, such as multiple mating and male annoyance, can have negative effects. In addition, this kind of interactions may also markedly decrease the ability to mass rear of biological control agents (Hardy et al., 2005; Li et al., 2014). There are many species of bugs that have been used as natural enemies in different regions, and their feeding habits, population establishment and interaction with other predators have been studied intensively (Tavella et al., 2000). Anthocoris are an insect group of natural enemies which are widely used as biological control agents of pests, including psyllids, thrips, mites and aphids (Lattin, 1999). The predatory insects, Anthocoris nemoralis (Fabricius, 1794) and Anthocoris nemorum (Linnaeus, 1761), have an important role in biological control programs, and are commercially produced because of their potential to be used in the management of common pistachio psyllids (Sigsgaard et al., 2006). The predatory bug, Anthocoris minki Dohrn, 1860, is another important species used to manage the common pistachio psyllid, Agonoscena pistaciae Burckhardt \& Lauterer, 1989, which is considered a serious pest causing severe yield loss in pistachio production in Asia, the Middle East and Mediterranean regions, including Turkey (Burckhardt \& Lauterer, 1993; Mart et al., 1995; Lauterer et al., 1998). In a field study conducted in pistachio growing areas in the Southeastern Anatolia Region of Turkey, A. minki was reported as a beneficial insect (Bolu, 2002). Another field study conducted by (Yanik \& Unlu, 2015), where A. minki was released to control the pistachio psyllid in pistachio orchards in Şanlıurfa, Turkey and was found to give a remarkable reduction $(82 \%)$ in the population density of $A$. pistaciae. Consequently, $A$. minki is considered an effective native natural enemy for biological control of this insect pest. The chemical control of common pistachio psyllid is problematic because of decreased effectiveness of the pesticides used, and some studies conducted in Iran have shown the existence of pistachio psyllids resistant to many insecticides (Mehrnejad, 2001; Alizadeh et al., 2011). In Turkey, there have been no investigations on the development of insecticide resistance in $A$. pistaciae. Therefore, gaining a comprehensive understanding of what can affect the mating and reproduction behavior of $A$. minki may help in assessing their effectiveness in both natural and agricultural ecosystems. This study aims to characterize the mating, reproduction and the intersexual interactions of $A$. minki species and thereby offer an opportunity to address specific questions related to male and female reproduction biology: How many copulations can successfully occur per unit time? Does the mating status (mated or unmated female) have a bearing on male acceptance and female longevity? Can male density and copulation duration affect egg lay? The results may also highlight many ways in which we could make breakthroughs the cost-effectiveness and convenience of mass production systems for A. minki.

\section{Material and Methods}

\section{Material}

A population of predatory insect $A$. minki was cultured under laboratory conditions at $25 \pm 1^{\circ} \mathrm{C}$, $60 \pm 10 \% \mathrm{RH}$ and 16:8 $\mathrm{h}$ L:D photoperiod, and fed on eggs of Mediterranean flour moth, Ephestia kuehniella Zeller, 1879 (Lepidoptera: Pyralidae) (Schmidt et al., 1995). Fresh bean pods were added to the culture to provide moisture, supplementary food and an egg laying sites. Fifth instar nymphs were separated into ventilated vials $(70 \mathrm{~mm}$ ) with prey (E. kuehniella eggs) and wet cotton sheet composed of two layers until they reached adulthood stage, then they transferred in groups into well ventilated plastic containers. All bugs used in this study were those that had newly reached the adulthood stage (1-2 $d$ for males and 2-3 $d$ for females). Sex separation was done using the well-known sexual dimorphism in the abdominal and antennal characters which is common in Anthocoridae. The bean pods were replaced every $3 \mathrm{~d}$. Eggs laid on the bean pods were checked daily under a microscope and counted. The study was conducted in a controlled-environment chamber at Department of Plant Protection, Faculty of Agriculture, Harran University in 2015. 


\section{Oviposition of virgin females}

Thirty virgin females of $A$. minki were individually placed in Petri dishes $(50 \mathrm{~mm})$. Females were fed on prey eggs. Bean pods were also placed in the Petri dishes to provide oviposition sites and replaced every $3 \mathrm{~d}$. The pods were regularly checked under a microscope to determine if eggs had been laid.

\section{Female tendency to multiple mating}

Female tendency to multiple mating was determined by testing the tendency of once mated females to re-mating. In this experiment, four virgin females (2- to 3-d-old) were placed separately in the courtship arena (50-mm Petri dishes) and one virgin male (1- to 2-d-old) was added to each virgin female to achieve the first copulation, and the copulation periods were recorded in minutes. After the first mating, the males were immediately removed with an aspirator without disturbing the mating and the female were left into their experimental arenas. Fresh bean pods and flour moth eggs were provided to females to lay their eggs. To examine the tendency of the mated females to re-mating with other virgin males, except the female in the first arena, other females were given an opportunity to mate again with a virgin male $1 \mathrm{~d}$ after the first mating. Seven days later, except the females in the first and second arenas, the rest of the females were allowed to mate for a third time with virgin males. Lastly, only the female in the fourth arena was given a chance to mate for the fourth time; $14 \mathrm{~d}$ after the first mating. Therefore, the females in the first to fourth arenas were given the opportunity to mate one to four times, respectively. The lifespan of each female was calculated in days to estimate the effect of the copulation number on female lifespan. In order to compare the longevity of mated and unmated females, a parallel experiment was set up where five adult virgin females were kept individually and the longevity recorded daily. The experiment was laid out in a completely randomized design with ten replicates. Additionally, egg laying rate was assessed for once mated females. Egg number was counted every $5 \mathrm{~d}$, throughout their lifespan. The first count was made $5 \mathrm{~d}$ after mating (referred to as day 1-5), the second count was made $10 \mathrm{~d}$ after mating (day 6-10), and counts were made nine times. Data were also recorded for the total number of eggs laid per female per day.

\section{Effect of male density on female reproduction}

The effect of male density on female reproduction was investigated by placing once mated female with $0,1,3$ and 5 males in the same experimental arena. In this experiment, five virgin females (2- to 3-dold) were individually placed in Petri dishes, then one virgin male (1- to 2-d-old) was introduced to each Petri dish. The mating behavior was observed and the copulation duration was recorded. Once the first mating was over, the males were removed and the females each transferred to a new Petri dish (i.e. five new Petri dishes in total) and new moth eggs and bean pods were provided. The effect of male density on once mated female reproduction was evaluated by adding $0,1,3$ and 5 virgin males into the first to fourth Petri dish, respectively. The once mated female in the fifth Petri dish was given five virgin females; and thus, saved as an experiment control to determine whether the male-female or female-female interactions would affect the reproductive performance. The total number of eggs and egg hatch percentage were recorded over the lifespan of each female. If bugs used in this experiment died, especially males or virgin females, were immediately replaced. The experiment was conducted in a completely randomized design with sixteen replicates.

\section{Male fertilization capacity}

In order to examine the mating behavior and fertilization capacity of single males, males (2- to 3-d-old) were given the opportunity to mate with three females sequentially with 0,1 or $2 \mathrm{~d}$ between mating events. In this experiment, three virgin males were individually placed in Petri dishes and the male in the first arena was allowed to mate with three virgin females, sequentially within the same day; the male in the second arena was allowed to sequentially mate with three virgin females, with 1 - $d$ interval between the mating sessions; and the male in the third arena was allowed to sequentially mate with three females, with 2-d intervals between the mating. The duration of all copulations was recorded. For each male, the first to third copulation was separated by intervals of 0,1 or $2 \mathrm{~d}$. At the end of the experiment, all males 
were kept in ventilated plastic arenas with prey eggs and their lifespan was recorded daily. As a control, 22 virgin males were kept in separated arenas with food and bean pods, and their lifespan recorded. Concurrently, all mated females were kept in Petri dishes with prey eggs and bean pods, then the total eggs and percentage hatch were recorded. Throughout the experiment, the males that died were substituted by males that newly reached adulthood, so that the number of adult males was consistent throughout the experiment. The experiment was replicated eight times in a completely randomized design.

\section{Statistical analysis}

In data analysis, the variance analysis was performed, and the difference between the averages was determined by Duncan's multiple comparison test at $P<0.05$. Student's t-tests were used to compare the mean differences in longevity between mated and unmated males and females. To explore the relationship of the longevity with egg laying of female, a correlation analysis was performed.

\section{Results}

\section{Oviposition by virgin females}

During this study, we did not observe any eggs laid by virgin female used in the experiments at any stage during their lifespan. Thus, we conclude that any oviposition event was as a successful mating.

\section{Female tendency to multiple mating}

All females $(n=40)$ in this experiment oviposited within 1-2 d after their first mating. Regardless of the interval between mating events, the successfully mated females showed a clear tendency to refuse any additional copulation. However, the Petri dishes had been shaken hand, therefore the females were forced to have additional mating. A significant reduction in the number of eggs after the second mating was observed with the increasing number of copulations (Table 1). Statistically, the average number of eggs laid by the four-times-mated females was significantly fewer when compared with the eggs laid by once-, twice- or three-times-mated females $(F=1.53, P<0.05)$. The effect of multiple mating on female lifespan was not statistically different $(F=0.92, P>0.05)$.

Table 1. The effect of multiple mating events on egg production and female lifespan

\begin{tabular}{|c|c|c|}
\hline Mating events & Egg number (mean \pm SEM)* & Lifespan (d) (mean \pm SEM) \\
\hline 1 & $102.1 \pm 0.69$ & $41.8 \pm 0.47 \quad a$ \\
\hline 2 & $125.1 \pm 0.65 \quad \mathrm{a}$ & $43.1 \pm 0.62 \quad a$ \\
\hline 3 & $99 \pm 0.52 \quad b$ & $39.6 \pm 0.52 \quad a$ \\
\hline 4 & $61 \pm 0.33 \quad b$ & $32.8 \pm 0.06 \quad a$ \\
\hline
\end{tabular}

${ }^{*}$ Means in the same column labeled with the same letter are not significantly different according to Duncan's multiple range test $(P<0.05)$.

The total number of eggs laid per female per day was 3-4 eggs during the first 4 weeks of oviposition, after which oviposition dropped markedly (Table 2). Throughout the oviposition period, females lay an average three eggs per day, but on some days, they did not lay any eggs. 
Table 2. Oviposition rate throughout the lifespan of once mated female of the predator bug, Anthocoris minki

\begin{tabular}{ccl}
\hline Days after the first mating & Average eggs/female/d (mean \pm SEM) \\
\hline $1-5$ & $3.2 \pm 0.26$ & a \\
$6-10$ & $4.0 \pm 0.38$ & a \\
$11-15$ & $4.2 \pm 0.36$ & a \\
$16-20$ & $3.7 \pm 0.48$ & a \\
$21-25$ & $3.5 \pm 0.41$ & a \\
$26-30$ & $3.3 \pm 0.50$ & a \\
$31-35$ & $1.2 \pm 0.36$ & b \\
$36-40$ & $0.4 \pm 0.36$ & c \\
$41-45$ & $0.0 \pm 0.00$ & c \\
\hline
\end{tabular}

${ }^{*}$ Means in the same column labeled with the same letter are not significantly different according to Duncan's multiple range test $(P<0.05)$.

There was a significant difference between the mated and unmated females in term of longevity $(t=2.16$, $d f=53, P=0.02)$. On average, the longevity of virgin females $(47.6 \pm 2 d, n=20)$, was found to be $25 \%$ longer than of mated females $(37.0 \pm 2 \mathrm{~d}, \mathrm{n}=40)$ (Figure 1).

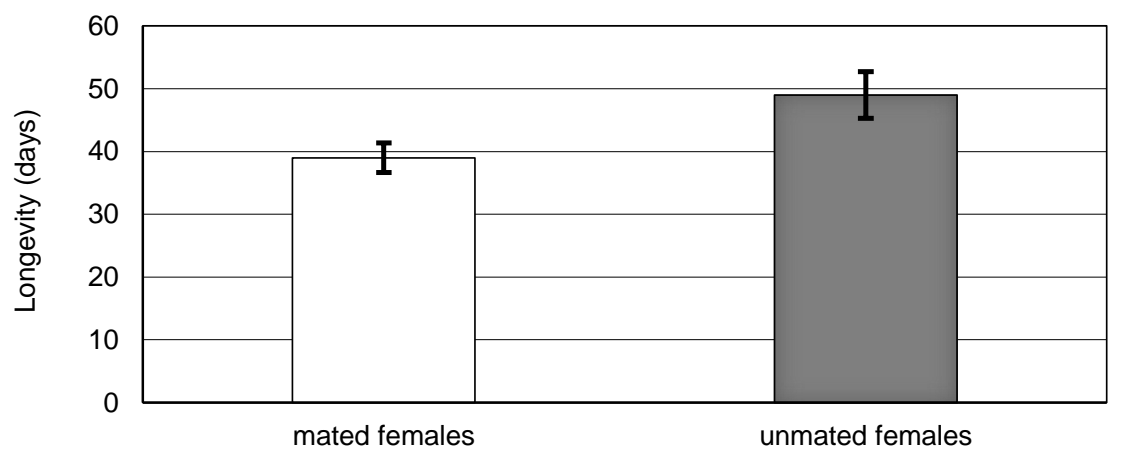

Figure 1. The effect of mating on female lifespan (bars represent the SEM).

\section{Effect of male density on female reproduction}

There was a significant steady decrease $(F=40.2, P<0.05)$ observed in the number of eggs in parallel with the increasing number of males (Table 3). This may be an indicator of the negative effect of male presence on the egg deposition of mated females. There was no significant difference between the females held alone and those held with one male in the total number of eggs $(F=2.78, P=0.08)$. In addition, the total eggs laid by the once mated females held with five virgin females was significantly $(F=7.37, P=0.02)$ fewer than those held alone. The eggs laid by the females held with five males was $38 \%$ fewer than by the females held with five virgin females. However, the percentage hatch $(91.06 \pm 1.23 \%)$ was not significantly affected by male density. There was no significant effect $(F=2.44, P=0.09)$ of male density on the longevity of mated females. In addition, there was no significant difference $(P=0.06)$ in longevity of females held alone and those held with five males, but there was a significant difference $(F=9.15, P=0.03)$ in longevity between females held with three or five males and those held with five virgin females. 
Table 3. Effect of the male density on mated female egg production, percentage of hatching eggs and longevity

\begin{tabular}{|c|c|c|c|}
\hline Male density & $\begin{array}{l}\text { Number of eggs per female } \\
\quad(\text { mean } \pm \text { SEM })^{*}\end{array}$ & $\begin{array}{l}\text { Percent hatch } \\
\text { (mean } \pm \text { SEM) }\end{array}$ & $\begin{array}{l}\text { Female longevity }(\mathrm{d}) \\
\quad(\text { mean } \pm \text { SEM })\end{array}$ \\
\hline No males (lone female) & $82.6 \pm 0.73 \quad a$ & $90.6 \pm 0.11 \quad a$ & $41.8 \pm 0.02 \quad a$ \\
\hline One male & $79.6 \pm 0.30 \quad a$ & $89.6 \pm 0.39 a$ & $39.7 \pm 0.88$ \\
\hline Three males & $52.6 \pm 0.71 \quad c$ & $90.2 \pm 0.24 \quad a$ & $38.3 \pm 0.46 \quad a$ \\
\hline Five males & $44.0 \pm 0.99 \mathrm{~d}$ & $91.4 \pm 0.39 \quad \mathrm{a}$ & $38.5 \pm 0.93 \quad a$ \\
\hline $\begin{array}{l}\text { Five virgin females with a } \\
\text { mated female }\end{array}$ & $71.8 \pm 0.38 \quad b$ & $93.2 \pm 0.03 \quad a$ & $37.8 \pm 0.32$ \\
\hline
\end{tabular}

* Means in the same column labeled with the same letter are not significantly different according to Duncan's multiple range test $(P<0.05)$.

Female longevity was positively correlated with the total number of eggs per female $\left(R^{2}=0.53, F=44.64\right.$, $\mathrm{df}=10, \mathrm{P}=0.02)$. Egg production ranged from 41 to 120 eggs per female and averaged $90.82 \pm 0.75$ (mean \pm SE) (Figure 2).



Figure 2. Relationship between longevity and total egg production of once mated Anthocoris minki females (data are fit with a linear regression).

\section{Male fertilization capacity}

There was no significant difference $(F=0.63, P>0.05)$ between the copulation periods when the same male was sequentially inseminated three different females with $2 \mathrm{~d}$ between matings (Table 4). However, when the three mating events were on the same day or separated by $1 \mathrm{~d}$, there was a significant difference $(F=18.2, P<0.05$ and $F=4.64, P<0.05$, respectively) in the time spent in the first compared to the second and third matings.

Table 4. Effect of time (0,1 and $2 \mathrm{~d}$ ) between mating attempts on the copulation period (same day: one male mated with three females within $1 \mathrm{~d}$; 1 -d interval: one male mated with three females by giving 1 -d interval between $1^{\text {st }}, 2^{\text {nd }}$ and $3^{\text {rd }}$ copulation; 2-d interval: one male mating with three females by giving 2-d interval between $1^{\mathrm{st}} 2^{\text {nd }}$ and $3^{\text {rd }}$ copulation)

\begin{tabular}{lccc}
\hline \multirow{2}{*}{ Interval (d) } & \multicolumn{3}{c}{ Copulation periods $(\mathrm{min})^{*}$} \\
\cline { 2 - 4 } & $1^{\text {st }}$ Copulation & $2^{\text {nd }}$ Copulation & $3^{\text {rd }}$ Copulation \\
\hline 0 (same day) & $15.35 \mathrm{aA}$ & $6.14 \mathrm{cB}$ & $4.13 \mathrm{cB}$ \\
1 & $15.16 \mathrm{aA}$ & $11.31 \mathrm{bB}$ & $8.35 \mathrm{bB}$ \\
2 & $16.23 \mathrm{aA}$ & $15.30 \mathrm{aA}$ & $14.14 \mathrm{aA}$
\end{tabular}

\footnotetext{
* Means labeled with the same letter (lowercase within columns and uppercase within rows) are not significantly different according to Duncan's multiple range test at $(\mathrm{P}<0.05)$.
} 
Furthermore, when the time interval between the copulations was $1 \mathrm{~d}$, a steady decrease in copulation duration has been observed among the three mating events $(15.16,11.31$ and 8.35 min, respectively). Significantly fewer $(P<0.05)$ eggs were laid by the third female than that laid by the first or second females (Figure 3$)$. When the three copulations were on the same day, a significant difference $(F=15.8$, $\mathrm{df}=4, \mathrm{P}=0.02)$ in the average of eggs laid was observed. Moreover, with $1 \mathrm{~d}(\mathrm{~F}=7.40, \mathrm{df}=4, \mathrm{P}<0.05)$ or $2 \mathrm{~d}(\mathrm{~F}=9.64, \mathrm{df}=2, \mathrm{P}<0.05)$ intervals, the third mated female laid significantly fewer eggs.

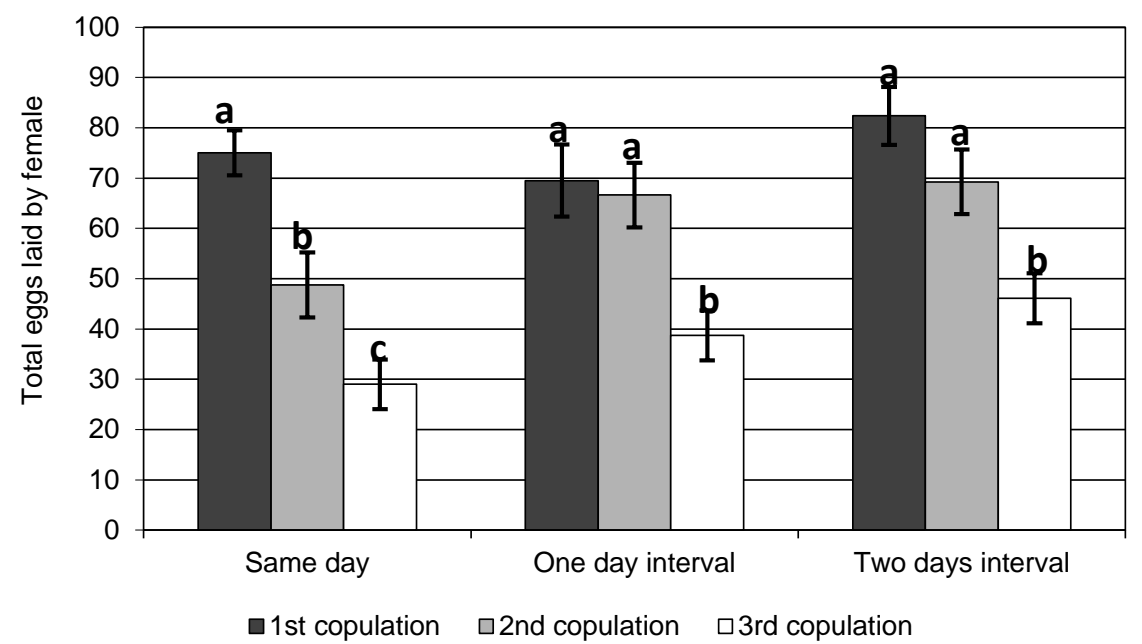

Figure 3. Effect of time $(0,1$ and $2 \mathrm{~d}$ ) between mating attempts on the total number of eggs laid. Bars with the same letter means that there is no significant difference according to Duncan's multiple range test at $(P<0.05)$.

The interval between copulations were not observed to have any negative effect on the fertilization capability of $A$. minki males. The number of matings and the interval between the first, second and third mating had no significant effect on the egg hatch rate. No significant differences $(P>0.05)$ in the longevity of females mated at different intervals were observed (Figure 4). According to the statistical analysis, copulations on the same day $(F=0.69, P>0.05)$, or at $1-d$ interval $(F=0.36, P>0.05)$ or $2-d$ interval $(F=0.12, P>0.05)$ had no significant effect on female longevity.

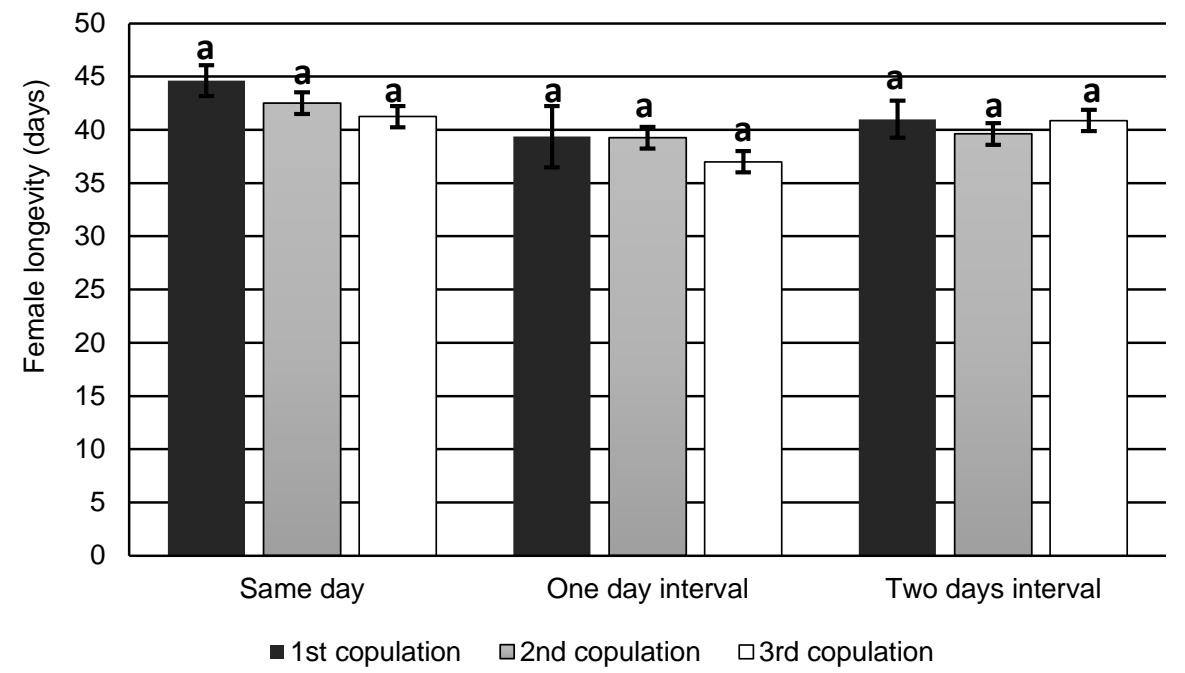

Figure 4. Effect of time (0,1 and $2 \mathrm{~d}$ ) between mating attempts on the female longevity (same day: one male mating with three females within $1 \mathrm{~d}$; 1 -d interval: one male mating with three females by giving $1-d$ interval between $1^{\text {st, }} 2^{\text {nd }}$ and $3^{\text {rd }}$ copulation; 2-d interval: one male mating with three females by giving 2-d interval between $1^{\text {st, }} 2^{\text {nd }}$ and $3^{\text {rd }}$ copulation). Bars with the same letter do not differ significantly according to Duncan's multiple range test at $(P<0.05)$. 
The average longevity of mated and unmated males was not significantly different $(t=0.69, \mathrm{df}=44$, $P=0.69)$ (Figure 5).

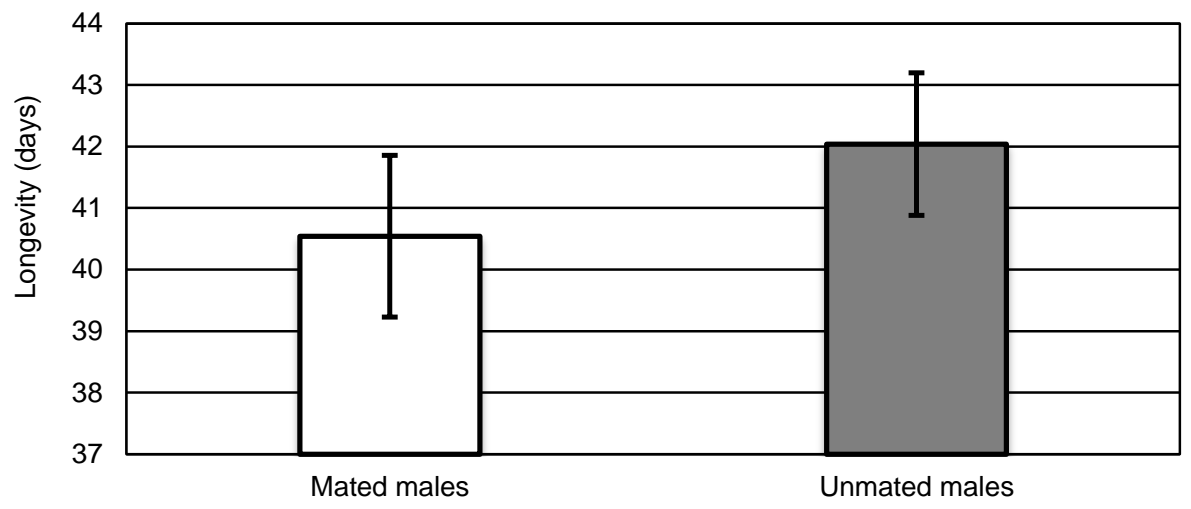

Figure 5. Effect of mating on male lifespan (bars represent the SEM).

\section{Discussion}

In this study, females tended to mate only once and most of them avoided the multiple mating regardless of length of the period given between mating events. The females did not lay eggs unless they were mated and once mated, they deposited eggs throughout their lives. This situation occurs because after mating, females retain sperm in their sperm storage tubules and use it to fertilize the eggs over a long period of time (Scudder, 1971; Leon-Beck \& Coll, 2009). There are significant differences in longevity between mated and virgin females; this can probably be attributed to energy that has been depleted in the mating or in the egg laying process (Thornhill \& Alcock, 1983; Arnqvist \& Nilsson, 2000; Simmons \& Kotiaho, 2007; Leon-Beck \& Coll, 2009). A clear relationship between male density and female reproduction was found. Fewer eggs were deposited by females kept with the larger numbers of males compared to those kept with the smaller numbers of males. Multiple mating appeared to have had a negative effect on egg deposition. It is likely that male density is only influencing the oviposition process, not the viability of eggs, because the male density did not affect egg hatch. In addition, female longevity decreased as male density increase. Egg laying was positively correlated with female lifespan, therefore, the reduction in offspring with increased male density may indicate the impact of male intensity on female lifespan. As reported by ( $\mathrm{Li}$ et al., 2014), the post-mating intersexual interactions may negatively influence both males and females in terms of reproductive performance. Most common malefemale interactions occur in $A$. minki are male annoyance and female reluctance. These interactions clearly reduced female longevity and fecundity. However, multiple mating and post-mating interactions had no effect on male longevity. Males of $A$. minki are generally adapted to multiple mating, since every single male successfully inseminated three females without affecting their lifespan. When three mating events occurred on the same day, the time spent in the second and third mating was less, while this period was similar to when the interval was 1 or $2 \mathrm{~d}$. These results suggest that male fertilization success does not depend on the male resting period as much as it depends on the number of copulations achieved. As reported by Linley \& Hinds (1974), Cook (1999), Leon-Beck \& Coll (2009) for Culicoides melleus (Coq., 1901) (Diptera: Ceratopogonidae), Plodia interpunctella (Hubner, 1813) (Lepidoptera; Pyralidae) and Orius laevigatus (Fieber, 1860) (Hemiptera: Anthocoridae), the gradual decrease in the sperm is probably the main reason for the gradual decline of the number of eggs laid by subsequent or later mated females as a result of deficient fertilization. There were different responses between males and females in their tendencies towards multiple matings. Females did not all start laying eggs on the same day, nor did they continue laying for the same length of time. Our results suggest that the mated females do not need to be kept in an insect rearing facility for more than 1 month because the number of eggs laid rose from the $10^{\text {th }}$ day and declined after the $30^{\text {th }}$ day, so mass production of $A$. minki can be achieved at low cost and over a short period of time. 


\section{References}

Alizadeh, A., K. Talebi, V. Hosseininaveh \& M. Ghadamyari, 2011. Metabolic resistance mechanisms to phosalone in the common pistachio psyllid Agonoscena pistaciae (Hem: Pysllidae). Pesticide Biochemistry and Physiology, 101: $59-64$

Arnqvist, G. \& T. Nilsson, 2000. The evolution of polyandry: multiple mating and female fitness in insects. Animal Behaviour, 60: 145-164.

Bolu, H., 2002. Güneydoğu Anadolu Bölgesi antepfıstığı alanlarındaki böcek ve akar faunasının saptanması. Türkiye Entomoloji Dergisi, 26 (3): 197-208.

Burckhardt, D. \& P. Lauterer, 1993. The jumping plant-lice of Iran (Homoptera; Psylloidea). Revue Suisse de Zoologie, 100: 829-898.

Cook, P. A., 1999. Sperm numbers and female fertility in the moth Plodia interpunctella (Hubner) (Lepidoptera; Pyralidae). Journal of Insect Behavior, 12: 767-779.

Hardy, I. C. W., P. J. Ode \& M. T. Siva-Jothy, 2005. "Mating behavior, 219-260". In: Insects as Natural Enemies: A Practical Perspective (Ed. M. A. Jervis). Springer, New York, USA, 748 pp.

Lattin, J. D., 1999. Bionomics of the Anthocoridae. Annual Review of Entomology, 44: 207-231.

Lauterer P., T. Broumas, S. Drosopoulos, C. Soulitis \& A. Tsourgianni, 1998. Species of the genus Agonoscena, pests on pistacia and first record of $A$. pistaciae in Greece. Annals de Institut Phytopathologique Benaki, 18: 123-128.

Leon-Beck, M. \& M. Coll, 2009. The mating system of the flower bug Orius laevigatus. Biological Control, 50:199-203.

Li, X. W., H. X. Jiang, X. C. Zhang, A. M. Shelton \& J. N. Feng, 2014. Post-mating interactions and their effects on fitness of female and male Echinothrips americanus (Thysanoptera: Thripidae), a new insect pest in China. PLoS ONE 9 (1): e87725.

Linley, J. R. \& M. J. Hinds, 1974. Male potency in Culicoides melleus (Coq.) (Diptera: Ceratopogonidae). Bulletin of Entomological Research, 64: 123-128.

Mart, C., L. Erkilic, H. Bolu, N. Uygun \& M. Altin, 1995. Species and pest control methods used in pistachio orchards of Turkey. Acta Horticulturae, 419: 379-386.

Mehrnejad, M. R., 2001. The current status of pistachio pests in Iran. Cahiers Options Méditerranéennes, 56: 315322.

Schmidt, J. M., P. C. Richards, H. Nadel \& G. Ferguson, 1995. A rearing method for the production of large numbers of the insidious flower bug Orius insidiosus (Say) (Hemiptera: Anthocoridae), Canadian Entomologist, 127 (3): 445-447.

Scudder, G. G. E., 1971. Comparative morphology of insect genitalia. Annual Review of Entomology, 16: 379-406.

Sigsgaard, L., P. Esbjerg \& H. Philipsen, 2006. Controlling pear psyllids by mass-releasing Anthocoris nemoralis and A. nemorum (Heteroptera: Anthocoridae). Journal of Fruit and Ornamental Plant Research, 14: 89-98.

Simmons, L. W. \& J. S. Kotiaho, 2007. The effects of reproduction on courtship, fertility and longevity within and between alternative male mating tactics of the horned beetle, Onthophagus binodis. Journal of Evolutionary Biology, 20: 488-495.

Tavella, I., R. Tedeschi, A. Arzone \& A. Alma, 2000. Predatory activity of two Orius species on the western flower thrips in protected pepper crops (Ligurian Riviera, Italy). International Organization of Biological and Integrated Control, WPRS Bulletin, 23: 231-240.

Thornhill, R. \& J. Alcock, 1983. The evolution of insect mating systems. Florida Entomological Society, 67: $180-182$.

Yanik, E. \& L. Unlu, 2015. Initial study of rearing and release of Anthocoris minki Dohrn (Hemiptera: Anthocoridea) for biological control of Agonoscena pistaciae Burckhardt and Lauterer (Hemiptera: Psyllidae) in pistachio orchards. Agriculture and Forestry, 61 (4): 347-358. 